\title{
After the storm: the photonics education and training landscape in Ontario
}

\section{Marc Nantel}

Marc Nantel, "After the storm: the photonics education and training landscape in Ontario," Proc. SPIE 9664, Ninth International Topical Meeting on

Education and Training in Optics and Photonics, 966409 (24 October 2005); doi: $10.1117 / 12.2207569$

Event: Ninth International Topical Meeting on Education and Training in Optics and Photonics, 2005, Marseille, France 


\title{
Ref ETOP018
}

\section{After the storm: the photonics education and training landscape in Ontario}

\author{
Marc Nantel
}

Photonics Research Ontario (a Division of OCE Inc), Toronto, Ontario, Canada

\begin{abstract}
It has been 5 years since the first of an organized effort to bring more undergraduate photonics education and training to Ontario schools has started. Before 2000, there were no photonics certificates, diplomas, or degrees other M.Sc. and Ph.D. available in the province. Now one can study to obtain optical fibre certificates and photonics technician/technologists diplomas at colleges, undergraduate degrees in photonics at colleges and universities, and continuing education certificates and diplomas in photonics. This talk gives an overview of the sea of changes in the field of photonics education and training that has shaped Ontario over the past half-decade.
\end{abstract}

\section{The calm before...}

\section{Summary}

In the years leading up to the incredible telecommunications/photonics bubble of the late 1990s, there were few regions in the world ready to handle the extra demand in personnel qualified in optics, lasers and photonics that would soon be unleashed. Places like Rochester, NY, USA, with its extensive programs in optics at the University of Rochester, the Rochester Institute of Technology and Monroe Community College, were already serving an active local population of companies like Eastman-Kodak, Xerox and Corning. They had the programs in place to cover all needs in photonics, from technicians to PhDs. Québec City, QC, Canada, was another such place, with photonics programs at Université Laval and several colleges in the area. Europe, Asia and Australia also had similar pockets, to varying degree of development.

Ontario, the largest province in Canada and the hub of much of the country's photonics innovation and industry was not ready. While it featured world-class photonics research programs at national laboratories and universities, most of these worked toward producing Master's and PhD-level scientists. Physics, Chemistry and Engineering department offered courses in optics as part of their curriculum, but there were no undergraduate programs leading to a credential in photonics. In most cases, one had to get to graduate school before working with optics meaningfully. This was generally not seen as a problem until the storm hit...

\section{Photonics' perfect storm...}

When the demand for photonics products - especially optical fibres and all things telecom - started to increase, it created a corresponding demand in industry for employees knowledgeable in the subject. In Ontario, home of Nortel Networks, JDS Uniphase, Lumonics and other photonics giants, this increased demand for qualified workforce became the limiting factor for growth in a highly-strategic industry. Not only were there too few photonics experts coming out of Ontario's educational institutions, but 
in the majority of cases, those becoming available were over-qualified. There was an urgent need for assemblers, technicians and engineers with photonics knowledge to design, build, package, test, sell and service all these products, not just MSc and PhD researchers to invent them.

In 1999, at the height of this photonics frenzy, Photonics Research Ontario set out a plan to address the need for photonics personnel in its entirety to relieve this bottleneck and allow for growth in the sector. ${ }^{1}$ This led in 2000 to the start of a project at Niagara College and Algonquin College to establish 1-year certificates, 2-year technician and 3year technology diplomas in photonics. The program took in its first cohort in Fall 2001 and has been running ever since. This project was the first to see students, but soon thereafter many new photonics offering became available at universities (Waterloo, McMaster, Wilfrid Laurier), ${ }^{2}$ private colleges (CCBC) and independent training providers (Vitesse (Re-Skilling) Canada). A 4-year Bachelor of Applied Technology - Photonics was added in 2004 to the Niagara/Algonquin offerings. To fill the pipeline being established at the upper end, the efforts in science and technology outreach to grade/mid/high-school students was intensified to provide more visibility to photonics and its potential as a career choice.

With all this activity in photonics education and training taking place, a coordinating influence was needed and the Ontario Photonics Education and Training Association (OPETA) was formed, regrouping all the major stakeholders in the field (educational, industrial, governmental and non-profit). Ontario was on the way to becoming one of those lucky jurisdictions where the whole photonics education and training pyramid was to be filled, from grade school to grad school (see figure 1). ${ }^{3}$

...in the middle of the fury, the distinct "pop!" of a bubble bursting...

While all this was going on, the bottom fell off the over-buoyed telecom market. The demand for optical fibre, then photonics devices, then telecom systems and test equipment catastrophically decreased in succession. Employees that were recently critical to the white-hot production of large photonics companies were no longer needed, multiple start-up companies flamed out and a deep freeze settled over the whole industry for 3 years.

The demand for newly-trained personnel nigh-completely stopped, putting in jeopardy the just-established photonics education and training programs in Ontario. Some changed to adapt, few kept their heads above water and some did not survive. OPETA's first mandate of coordinating the activities around new programs and the demand from industry morphed into one of survival. Nobody doubted that photonics would rebound eventually - and "photonics" is much bigger than just its telecom sector - but this downturn was occurring at a critical point in the growth of the education initiatives underway.

\section{...The silver lining and blue sky reappearing!}

Thankfully, industry's loss would become academia's gain. As large companies were shedding employees, they found themselves buried in now-unused equipment. This equipment was devaluating the companies stock and had also to be disposed of. OPETA was able to funnel \$4-million of such equipment to educational institutions in 
Ontario and elsewhere in Canada through 2002-2004, thereby greatly supporting the establishment of the photonics education and training programs in progress. Further equipment was donated directly from industry partners to colleges and universities or made available at bargain prices. Another $\$ 4$-million in equipment is estimated to have found its way into students' hands that way. Some of these donations were used to leverage government funding, further increasing their impact on the programs.

While other sectors like biophotonics, manufacturing, imaging/vision and environmental monitoring have continued to grow throughout telecom's cycle, much attention was focused on the latter because of the sheer magnitude of its up and down swing. It is clear now that growth - albeit a more sustainable one - has started again in the telecom aspects of photonics, that the other sectors are solid and that the decision to persevere with photonics education and training will reward those who stuck with it.

\section{Acknowledgements:}

The author would like to acknowledge funding from the Strategic Skills Investment Program or the Ontario Ministry of Economic Development and Trade.

\section{References}

1) M. Nantel and J. Beda, Photonics Education and Training in Ontario, Phys. Can. 58, 19 (2002); M. Nantel and Johann Beda, Photonics education and training in Ontario, Canada: an integrated plan, SPIE Proc. 4588A (2001).

2) M. Nantel, J. Beda, T. Grevatt, B. Chebbi, P. Jessop, and S. Song, Three new undergraduate degrees in photonics in Ontario, Phys. Can. 60, 319 (2004); M. Nantel, J. Beda, P. Jessop and S. Song, Three new bachelors of photonics in Ontario, SPIE Proc. 5578E (2004).

3) M. Nantel, On the importance of networking in physics education: multiple heads are better than one, Phys. Can. 61, 91 (2005); M. Nantel, The Ontario Photonics Education and Training Association (OPETA): L'union fait la force!, Proceedings of the 2003 Education and Training in Optics and Photonics Conference (2003) 